\title{
HYGIENE SANITATION AND DETECTION OF RHODAMIN B IN SAUCE AND FORMALIN IN MEATBALL AT MEATBALL TAVERN, KUPANG, EAST NUSA TENGGARA
}

\author{
Marthen Rachmad Here'), Pius Weraman'), Hari Rarindo') \\ ${ }^{1)}$ District Health Office, Sabu Raijua \\ 2)Masters Program in Public Health, Universitas Nusa Cendana
}

\begin{abstract}
Background: Food safety and sanitation is an essential part of the food industry. While it is important to be able to deliver food quickly and profitably, the importance of food safety and sanitation cannot be underestimated. Fast food retailers such as meatball tavern are common in Kupang, East Nusa Tenggara. Therefore it is worth studying the food safety and sanitation among the existing fast food retailers. This study aimed to examine hygiene sanitation and detection of rhodamin B in sauce and formalin in meatball at meatball tavern, Kupang, East Nusa Tenggara.

Subjects and Method: This was a cross-sectional study conducted at meatball taverns, Kupang, East Nusa Tenggara, Indonesia. A total of 16 meatball taverns were selected for this study by total sampling. The dependent variables were hygiene sanitation, rhodamine B content in sauce, and formalin content in meatball. The independent variables were selection of foodstuff, food storage, processing place, equipment, food handlers, food transport, and food provision. The data were collected by observation and laboratory examination. The data were described accordingly.

Results: Hygiene and sanitation in food selection and food storage were good (70$100 \%)$. Hygiene and sanitation in food handling and processing were fair (50$78 \%)$. Hygiene and sanitation of processing places were variable from poor to moderate (36-72\%). Hygiene and sanitation of equipment were good (70-100\%). Food stewardship was very good (87-100\%). Rhodamine B content was absent in sauce. Formalin content was absent in meatball.

Conclusion: Hygiene and sanitation levels in various aspect of food preparation and handling at meatball taverns were variable ranging from poor to very good level.
\end{abstract}

Keywords: hygiene, sanitation, meatball, tavern, formalin, rhodamin B.

\section{Correspondence:}

Marthen Rachmad Here. District Health Office, Sabu Raijua, East Nusa Tenggara, Indonesia. Email: marthenrachmadhere@gmail.com. Mobile: o81353789464. 